\title{
Annalisa Oboe and Shaul Bassi, Experiences of Freedom in Postcolonial Literatures and Cultures
}

\section{Adnan Mahmutovic}

\section{Q OpenEdition}

1 Journals

Electronic version

URL: https://journals.openedition.org/ces/5933

DOI: $10.4000 /$ ces.5933

ISSN: 2534-6695

Publisher

SEPC (Société d'études des pays du Commonwealth)

\section{Printed version}

Date of publication: 1 September 2012

Number of pages: 105-106

ISSN: 2270-0633

\section{Electronic reference}

Adnan Mahmutovic, "Annalisa Oboe and Shaul Bassi, Experiences of Freedom in Postcolonial Literatures and Cultures", Commonwealth Essays and Studies [Online], 35.1 | 2012, Online since 18 April 2021, connection on 23 July 2021. URL: http://journals.openedition.org/ces/5933 ; DOI: https://doi.org/ $10.4000 /$ ces.5933

This text was automatically generated on 23 July 2021 .

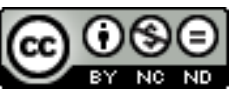

Commonwealth Essays and Studies is licensed under a Licence Creative Commons Attribution - Pas d'Utilisation Commerciale - Pas de Modification 4.0 International. 


\title{
Annalisa Oboe and Shaul Bassi, Experiences of Freedom in Postcolonial Literatures and Cultures
}

\author{
Adnan Mahmutovic
}

\section{REFERENCES}

Annalisa Oboe and Shaul Bassi. Experiences of Freedom in Postcolonial Literatures and Cultures. London and New York: Routledge, 2012. 366 p. ISBN (hb) 978-0415591911, ISBN (pb) 9780415591928 , ISBN (ebook) 9780203828922, 49.95\$ (pb)

1 Freedom, according to the editors of the volume, is "one of the central narratives of our late modern society" (3). The key word here is "narrative," because freedom is a story which began in many different places and histories as an expression of peoples' local concerns, and in some cases, such as the Greek polis, resulted in the development of the notion of citizenry. Freedom-as-narrative, apparently volatile and open to any practitioner, has now gone global and became commodified. For this reason, the authors of this rich array of articles, highlight the need to rethink freedom, to (re)experience it, to (re)narrate it, and (re)assert it. Most importantly, through all these gestures that arise from diverse ways of articulating and living life, there is a need to liberate "freedom" itself. The articles in this volume cover a wide range of topics related to the issue of freedom, and they are representative of many contemporary postcolonial studies of literature. The authors relate to many postcolonial places and histories. Africa is the most represented continent - we find analysis of topics related to Uganda, Biafra, Kenya, Ghana, South Africa, Nigeria, Sudan etc. - but there are articles about South America, the Indian subcontinent, Afghanistan, an even some work on America and global Islamism.

2 Such diversity of approaches and analyzed materials shows the import of the study of literature as a way of liberating freedom from commodification. In relation to overly 
theoretical articles, the analyses of literary works - including a few reflections by postcolonial authors such as Caryl Phillips and Anita Desai - show how literature still brings to crisis our common myths and ideologies, even the notion of freedom itself. The editors correctly point out that literature has often been used as the embellishing of theory, but the variegated articles inadvertently display a positive resistance of the materials analyzed to academic discourses. In fact, the numerous gaps opened up in/by diverse analyses show a resistance in "freedom" itself as a subject of analysis as well as its fragility.

3 No critic in this volume, regardless of the discipline, divests freedom of its discursive import. The notion of "trying freedom" - meaning both attempting to achieve it and to put it on trial, as the editors put it - makes freedom posit itself "as an essential constituent of the human experience in its manifold declinations" (6). This is in part done through a discourse on the entangled relationship between freedom and rights, freedom and resistance, freedom as movement, freedom as a deferred utopia, and freedom as creative engagement in the arts. Achille Mbembe reminds us of Nancy's argument that freedom is everything but an "Idea," that freedom is fragile insofar as it is used as if it were the Idea or a mere praxis geared towards a preconceived telos. The praxis of freedom may not be, in the final analysis, teleological.

4 Many authors in this volume show that to be able to use freedom synonymously with rights, resistance, and utopia presupposes the facticity of freedom. By discussing freedom in relation to these other important political concepts, they reveal constraints of traditional thought against which freedom can be thought. However, these collected analyses often produce some sense of nostalgia and past-orientation. They mostly deal with what Robert Young calls the safe past instances of freedom-praxis (such as resistance). Through their insistence on freedom as praxis or performativity, what some may miss to question is the un-threatening freedom of academic discourse itself. Young's deconstruction of resistance feeds into the paradoxes of freedom that some articles seem to articulate, either deliberately or as a side effect of other arguments. Resistance helps us realize freedom, but resistance as praxis-of-freedom is also a limitation of it. Freedom as praxis, rather than Nancy's facticity, is its own resistance. Instead of clashes of civilizations and ideologies, we may even speak of clashes of freedoms.

5 The four sections of the volume, albeit appropriately split, show a number of conflicts within the history, practice, and narration of freedom, conflicts which both create freedom as the Idea and undermine it as such. Although I would like to see a conclusive chapter that pinpoints the creative paradoxes of freedom which loom large through most articles and across the borders of different sections, I find that the strength of the present volume lies in the fact that the articles were not written for the sake of cohesiveness of a book on freedom. The strong-yet-loose ties between the articles, which all deserve to be read, in the final analysis open venues of (re)thinking, (re)experiencing, (re)narrating, and (re)asserting freedom. 